\title{
ANTIPLASMODIAL AND LARVICIDAL FLAVONOIDS FROM DERRIS TRIFOLIATA
}

\author{
Abiy Yenesew ${ }^{1, *}$, Hannington Twinomuhwezi ${ }^{1,2}$, Jacques M. Kabaru ${ }^{3}$, Hoseah M. Akala ${ }^{4}$, \\ Bernard T. Kiremire ${ }^{2}$, Matthias Heydenreich ${ }^{5}$, Martin G. Peter ${ }^{5}$, Fredrick L. Eyase ${ }^{4}$, Norman C. \\ Waters ${ }^{4}$ and Douglas S. Walsh ${ }^{4}$ \\ ${ }^{1}$ Department of Chemistry, University of Nairobi, P.O. Box 30197, Nairobi, Kenya \\ ${ }^{2}$ Department of Chemistry, Makerere University, P.O. Box 7062, Kampala, Uganda \\ ${ }^{3}$ School of Biological Sciences, University of Nairobi, P.O. Box 30197, Nairobi, Kenya \\ ${ }^{4}$ United States Army Medical Research Unit-Kenya, MRU 64109, APO, AE 09831-4109, USA \\ ${ }^{5}$ Institut für Chemie, Universität Potsdam, P.O. Box 6015 53, D-14415 Potsdam, Germany
}

(Received December 19, 2008; revised July 8, 2009)

\begin{abstract}
From the dichloromethane-methanol (1:1) extract of the seed pods of Derris trifoliata, a new flavanone derivative $(S)$-lupinifolin 4'-methyl ether was isolated. In addition, the known flavonoids lupinifolin and rotenone were identified. The structures were determined on the basis of spectroscopic evidence. Lupinfolin showed moderate in vitro antiplasmodial activity against the D6 (chloroquine-sensitive) and W2 (chloroquineresistant) strains of Plasmodium falciparum. The different parts of this plant showed larvicidal activities against Aedes aegypti and rotenoids were identified as the active principles.
\end{abstract}

KEY WORDS: Derris trifoliata, Leguminosae, Flavanone, $(S)$-Lupinifolin 4'-methyl ether, Lupinifolin, Antiplasmodial, Rotenoid, Larvicide, Aedes aegypti

\section{INTRODUCTION}

The genus Derris (Leguminosae) is a rich source of isoflavonoids, especially rotenoids [1]. Some Derris species are in fact cultivated and commercialized as a source of the insecticide rotenone [2]. In Kenya this genus is represented by Derris trifoliata. From the roots [3] and seeds [4] of this plant we have isolated unique isoflavonoid derivatives, rotenoloids and a spirohomo-oxarotenoid. Here we report the isolation and characterization of a new flavanone derivative (1) named (S)-lupinifolin 4'-methyl ether. The anti-plasmodial and larvicidal activities of some of the flavonoids of this plant are also presented.

\section{RESULTS AND DISCUSSION}

HRMS analysis of compound 1 showed a $[\mathrm{M}+1]^{+}$peak at $\mathrm{m} / \mathrm{z} 421.2002$ corresponding to the molecular formula of $\mathrm{C}_{26} \mathrm{H}_{28} \mathrm{O}_{5}$. The ${ }^{1} \mathrm{H}(\delta 5.35 d d, \mathrm{~J}=3.0,13.0$ for $\mathrm{H}-2 \mathrm{ax} ; 2.80 \mathrm{dd}, \mathrm{J}=3.0$, -17.0 for $\mathrm{H}-3_{\mathrm{eq}}$; and $3.05 d d, \mathrm{~J}=13.0,-17.0$ for $\left.\mathrm{H}-3_{\mathrm{ax}}\right)$ and ${ }^{13} \mathrm{C}(\delta 78.5$ for $\mathrm{C}-2,43.1$ for $\mathrm{C}-3$, 196.4 for C-4) NMR spectra showed this compound to be a flavanone derivative. Furthermore, the presence of a chelated hydroxyl at C-5, a methoxyl, a 2,2-dimethylpyran, and a 3,3dimethylallyl substituents was established from the NMR spectra (Table 1). In the ${ }^{1} \mathrm{H}$ NMR spectrum, the presence of an $\mathrm{AA}^{\prime} \mathrm{XX}^{\prime}$ spin system suggested that B-ring is substituted at C-4'. This substituent was established to be a methoxy $\left(\delta_{\mathrm{H}} 3.84, \delta_{\mathrm{C}} 55.3\right)$ from NOESY (interaction of the methoxy protons with $\mathrm{C}-3^{\prime} / 5^{\prime}$ ) and $\mathrm{HMBC}$ (correlation of $\mathrm{H}-2^{\prime} / 6^{\prime}$ with $\mathrm{C}-4^{\prime}, \mathrm{H}-3^{\prime} / 5^{\prime}$; and $\mathrm{OCH}_{3}$ with $\mathrm{C}-4^{\prime}$ ) spectra. It follows then that ring-A is fully substituted with hydroxyl (at $\mathrm{C}-5$ ), the 2,2-dimethylpyran and the 3,3-dimethylallyl groups. This was supported by the presence of an EI-MS fragment ion at $m / z 271$ (1a) which resulted from a retro-Diels Alder fragmentation

*Corresponding author. E-mail: ayenesew@uonbi.ac.ke 
of ring-C with loss of a methyl group from ring-A. The placement of the 3,3-dimethylallyl group at $\mathrm{C}-8$ and the 2,2-dimethylpyran group at C-6/7 was established from the HMBC spectrum (correlation of the methylene protons of the 3,3-dimethylallyl group with $\mathrm{C}-7$ and $\mathrm{C}-8 \mathrm{a}$; $\mathrm{H}-4$ " with C-5 and C-7; and correlation of the chelated $\mathrm{OH}$ with C-4a and C-6). The placement of the 2,2-dimethylpyran group at C-6/7 was confirmed by NOE interaction of $\mathrm{H}-4$ " with the chelated $\mathrm{OH}$. Therefore this compound was assigned structure 1 for which the trivial name lupinifolin $4^{\prime}-$ methyl ether is suggested by relating it to lupinifolin (2) a compound, which co-occurs in this plant. The CD spectrum and the negative optical rotation of compound $\mathbf{1}$ are consistent with an $S$ configuration at C-2 [5]. Methylation of compound 2 gave the methoxy derivative $\mathbf{1}$.

Table 1. NMR data for compounds 1 and $2\left(\mathrm{CDCl}_{3}\right),{ }^{1} \mathrm{H}(500 \mathrm{MHz})$ and ${ }^{13} \mathrm{C}(150 \mathrm{MHz})$.

\begin{tabular}{|c|c|c|c|c|c|}
\hline \multirow[t]{2}{*}{ Position } & \multicolumn{3}{|c|}{1} & \multicolumn{2}{|r|}{2} \\
\hline & $\delta_{\mathrm{C}}$ & $\delta_{\mathrm{H}}(J$ in $\mathrm{Hz})$ & HMBC & $\delta_{\mathrm{C}}$ & $\delta_{\mathrm{H}}(J$ in $\mathrm{Hz})$ \\
\hline 2 & 78.5 & $5.35 d d(3.0,13.0)$ & $\mathrm{C}-4$ & 78.5 & $5.35 d d(3.3,12.6)$ \\
\hline $3_{\mathrm{eq}}$ & \multirow{2}{*}{43.1} & $2.80 d d(3.0,-17.0)$ & $\mathrm{C}-2,4,1^{\prime}$ & \multirow{2}{*}{44.1} & $2.79 d d(3.3,-17.0)$ \\
\hline $3 a x$ & & $3.05 d d(13.0,-17.0)$ & C- $2,4,1^{\prime}$ & & $3.04 d d(12.6,-17.0)$ \\
\hline 4 & 196.4 & & & 196.6 & \\
\hline $4 a$ & $102.7^{\prime \prime}$ & & & $102.5^{*}$ & \\
\hline 5 & 156.6 & & & 156.5 & \\
\hline 6 & $102.8^{3}$ & & & $102.8^{*}$ & \\
\hline 7 & 159.8 & & & 160.0 & \\
\hline 8 & 108.6 & & & 108.7 & \\
\hline $8 \mathrm{a}$ & 159.4 & & & 159.4 & \\
\hline $1^{\prime}$ & 130.9 & & & 130.8 & \\
\hline $2^{\prime} / 6^{\prime}$ & 127.5 & $7.37 d(8.4)$ & $\mathrm{C}-3^{\prime} / 5^{\prime}, 4^{\prime}$ & 127.7 & $7.31 d(8.4)$ \\
\hline $3^{\prime} / 5^{\prime}$ & 114.1 & $6.94 d(8.4)$ & $\mathrm{C}-1^{\prime}, 4^{\prime}$ & 115.5 & $6.87 d(8.4)$ \\
\hline $4^{\prime}$ & 159.8 & & & 156.0 & \\
\hline $2^{\prime \prime}$ & 78.0 & & & 78.1 & \\
\hline $3^{\prime \prime}$ & 125.9 & $5.49 d(10.0)$ & C-6 & 126.0 & $5.50 d(10.2)$ \\
\hline $4^{\prime \prime \prime}$ & 115.7 & $6.63 d(10.0)$ & $\mathrm{C}-5,7$ & 115.6 & $6.63 d(10.2)$ \\
\hline $1^{\prime \prime \prime}$ & 21.5 & $3.21 d(7.2)$ & C-7, 8, 8a, 2"', 3"' & 21.5 & $3.20 d(7.2)$ \\
\hline $2 " \prime$ & 122.6 & $5.16 t(7.2)$ & & 122.6 & $5.16 t(7.2)$ \\
\hline $3 " \prime$ & 131.6 & & & 131.1 & \\
\hline $4^{\prime \prime \prime}$ & 25.8 & $1.65 s$ & $\mathrm{C}-3^{\prime \prime \prime}$ & 25.8 & $1.65 s$ \\
\hline $5^{\prime \prime \prime}$ & 17.8 & $1.65 s$ & $\mathrm{C}-3^{\prime \prime \prime}$ & 17.8 & $1.65 s$ \\
\hline $\mathrm{OCH}_{3}$ & 55.3 & $3.84 s$ & $\mathrm{C}-4^{\prime}$ & & \\
\hline $5-\mathrm{OH}$ & & $12.26 s$ & $\mathrm{C}-4 \mathrm{a}, 5,6$ & & $12.23 s$ \\
\hline
\end{tabular}

*Assignments may be interchangeable.<smiles>[R7]c1ccc([C@H]2CC(=O)c3c(O)c4c(c([CH-]C=C(F)[S-])c3O2)OC(C)(C)C=C4)cc1</smiles>

$1 \mathrm{R}=\mathrm{CH}_{3}$

$2 \mathrm{R}=\mathrm{H}$<smiles>CC(C)=CCC1=c2[o+]c(C)ccc2=C(O)C(C=O)C1=O</smiles>

$m / z 271$

Bull. Chem. Soc. Ethiop. 2009, 23(3) 
The seed pods of Derris trifoliata showed weak activity against the D6 and W2 strains of Plasmodium falciparum (Table 2). The major compounds isolated from this plant were also tested (Table 2), with the flavanone lupinfolin (2) being the most active with $\mathrm{IC}_{50}$ values of $2.6 \pm 0.8$ and $3.7 \pm 1.4 \mu \mathrm{g} / \mathrm{mL}$ against the D6 and $\mathrm{W} 2$ strains of Plasmodim falciparum, respectively. Lupinifolin $4^{\prime}$-methyl ether $(\mathbf{1})$ is less active $\left(\mathrm{IC}_{50}\right.$ values of $12.9 \pm 1.6$ and $15.0 \pm 2.5 \mu \mathrm{g} / \mathrm{mL}$ against the D6 and $\mathrm{W} 2$ strains, respectively) than lupinifolin showing the importance of free hydroxyl group at C-4' in compound $\mathbf{2}$ for anti-plasmodial activity. We have observed a similar trend for flavanones isolated from Erythrina species [6]. The in vivo antiplasmodial activity of these compounds is questionable. Compound $\mathbf{2}$ has recently been reported to exhibit a marked inhibitory effect on mouse skin tumor promotion in an in vivo twostage carcinogenesis test [7]. To the best of our knowledge, the cancer chemoprevention is one of the major activities of these compounds.

Table 2. In vitro $\mathrm{IC}_{50}$ values of the crude seed pods extract and flavonoids from $D$. trifoliata against W2 and D6 strains of Plasmodium falciparum.

\begin{tabular}{|l|l|l|}
\hline Tested samples & \multicolumn{2}{|c|}{$\mathrm{IC}_{50}(\mu \mathrm{g} / \mathrm{mL})$} \\
\hline & $\mathrm{D} 6$ & $\mathrm{~W} 2$ \\
\hline Seed pods extract & $12.2 \pm 2.4$ & $13.4 \pm 2.6$ \\
\hline Lupinifolin 4'-methyl ether (1) & $12.9 \pm 1.6$ & $15.0 \pm 2.5$ \\
\hline Lupinifolin (2) & $2.6 \pm 0.8$ & $3.7 \pm 1.4$ \\
\hline Rotenone & $3.8 \pm 1.6$ & $6.6 \pm 2.2$ \\
\hline Deguelin [3] & $6.3 \pm 1.8$ & $8.9 \pm 2.0$ \\
\hline 6.7-Dimethyl-4-chromanone [4] & $13.2 \pm 1.2$ & $15.7 \pm 2.3$ \\
\hline Chloroquine & $0.008 \pm 0.004$ & $0.051 \pm 0.010$ \\
\hline Mefloquine & $0.0420 \pm 0.008$ & $0.015 \pm 0.002$ \\
\hline
\end{tabular}

The various parts of Derris trifoliata were also tested for larvicidal activities against $2^{\text {nd }}$ instar larvae of Aedes aegypti and the results are summarized in Table 3. The seeds were the most active with $\mathrm{LC}_{50}$ value of $0.7 \pm 0.2 \mu \mathrm{g} / \mathrm{mL}$ at $24 \mathrm{~h}$. The seed extract is also potent against $3^{\text {rd }}$ $\left(\mathrm{LC}_{50}=3.7 \pm 1.5 \mu \mathrm{g} / \mathrm{mL}\right)$ and $4^{\text {th }}\left(\mathrm{LC}_{50}=8.5 \pm 2.3 \mu \mathrm{g} / \mathrm{mL}\right)$ instar larvae of Aedes aegypti. The major compounds isolated from this plant $[3,4]$ have also been tested and we have identified rotenoids, especially rotenone, to be the most active ingredient of this plant (Table 3).

Table 3. Activities of crude $\mathrm{CH}_{2} \mathrm{Cl}_{2} / \mathrm{MeOH}$ (1:1) extracts and pure compounds from Derris trifoliata against $2^{\text {nd }}$ instar larvae of Aedes aegypti.

\begin{tabular}{|l|l|}
\hline Tested samples & $\mathrm{LC}_{50}(\mu \mathrm{g} / \mathrm{mL})$ at $24 \mathrm{~h}$ \\
\hline Crude extracts (plant part) & \\
\hline Seeds & $0.7 \pm 0.2$ \\
\hline Roots & $1.4 \pm 0.5$ \\
\hline Stem & $8.6 \pm 1.3$ \\
\hline Leaves & $7.5 \pm 1.7$ \\
\hline Seed pods & $>20$ \\
\hline Pure compounds & \\
\hline Lupinifolin 4'-methyl ether (1) & $>20$ \\
\hline Lupinifolin (2) & $>20$ \\
\hline Rotenone & $0.5 \pm 0.2$ \\
\hline Deguelin [3] & $1.6 \pm 0.9$ \\
\hline Dehydrodeguelin [4] & $>20$ \\
\hline Tephrosin [4] & $1.5 \pm 0.8$ \\
\hline 6,7-Dimethoxy-4-chromone [4] & $13.4 \pm 2.7$ \\
\hline
\end{tabular}

Bull. Chem. Soc. Ethiop. 2009, 23(3) 
General

\section{EXPERIMENTAL}

Analytical TLC: Merck pre-coated silica gel $60 \mathrm{~F}_{254}$ plates. CC on oxalic acid impregnated silica gel 60 (70-230 mesh). UV spectra were measured on UV-1700 PharmaSpec, Shimadzu (Japan). EIMS: direct inlet, $70 \mathrm{eV}$, on a SSQ 710, Finnigan MAT mass spectrometer (USA). HRMS were recorded with electrospray ionisation on a ESI-QTOFmicro mass spectrometer from Waters Inc. (USA). ${ }^{1} \mathrm{H}-\mathrm{NMR}$ (500 or $200 \mathrm{MHz}$ ) and ${ }^{13} \mathrm{C}-\mathrm{NMR}$ (125 or $50 \mathrm{MHz}$ ) on Bruker (Germany) or Varian-Mercury spectrometers (USA) using TMS as internal standard. HMQC and HMBC spectra were acquired using the standard Bruker software. CD spectra were recorded on Jasco J-715 spectropolarimeter (Japan) and Optical rotations on a Jasco P-1020 polarimeter (Japan).

\section{Plant material}

For collection and authentication of Derris trifoliata, refer to reference [4].

\section{Extraction and isolation}

The dried and ground seed pods (280 g) of $D$. trifoliata were extracted with dichloromethanemethanol $(1: 1)$ by cold percolation $(3 \times 500 \mathrm{~mL})$. Removal of the solvent under reduced pressure afforded $27 \mathrm{~g}$ of crude extract. The extract was subjected to CC on silica gel $(300 \mathrm{~g})$ and eluted with hexane containing increasing amounts of dichloromethane. A total of 20 fractions each of ca. $750 \mathrm{~mL}$ were collected. The fraction eluted with $20 \% \mathrm{CH}_{2} \mathrm{Cl}_{2}$ in hexane was further purified by $\mathrm{CC}$ on Sephadex LH-20 (eluting with $\mathrm{CH}_{2} \mathrm{Cl}_{2}-\mathrm{MeOH} ; 1: 1$ ) and then on prep TLC (hexane- $\mathrm{CH}_{2} \mathrm{Cl}_{2}$ EtOAc; 6:3:1) to give compound $1(35 \mathrm{mg})$. The fractions eluted with $30 \% \mathrm{CH}_{2} \mathrm{Cl}_{2}$ in hexane showed two spots on TLC and these were separated by prep TLC (hexane- $\mathrm{CH}_{2} \mathrm{Cl}_{2}-\mathrm{EtOAc} ; 6: 3: 1$ ) to give rotenone $(36 \mathrm{mg}$ ) and compound $2(67 \mathrm{mg})$. The fractions eluted with $40 \%$ and $50 \%$ $\mathrm{CH}_{2} \mathrm{Cl}_{2}$ in hexane were combined and upon crystallization afforded more amounts of compound 2 (136 mg).

Lupinifolin 4'-methyl ether (1)

Pale yellow oil. UV $\lambda_{\max }^{\mathrm{MeOH}}(\log \varepsilon) \mathrm{nm}: 273$ (4.3), $312(3.8), 367$ (3.2). $[\alpha]_{D}^{26}=-65.7^{\circ}(\mathrm{MeOH}, \mathrm{c}$ 0.01). $\mathrm{CD}(\mathrm{MeOH}, 0.01):[\Theta]_{329}+9472,[\Theta]_{288}-3278 .{ }^{1} \mathrm{H}$ and ${ }^{13} \mathrm{C}$ NMR (Table 1). EIMS $\mathrm{m} / \mathrm{z}$ (rel int): $420\left(57,[\mathrm{M}]^{+}\right), 405\left(69,[\mathrm{M}-\mathrm{Me}]^{+}, 271\right.$ (52), $215\left(100, \mathrm{C}_{16} \mathrm{H}_{15} \mathrm{O}_{4}\right)$. HR-EIMS [M+1] found $\mathrm{m} / z 421.2002 \mathrm{C}_{26} \mathrm{H}_{29} \mathrm{O}_{5}$, calculated for 421.2015 .

\section{Methylation of lupinifolin (2)}

Lupinifolin $(10 \mathrm{mg})$ in dry acetone $(10 \mathrm{~mL})$, anhydrous $\mathrm{K}_{2} \mathrm{CO}_{3}(1 \mathrm{~g})$ and dry dimethyl sulfate $(20 \mu \mathrm{L})$ was refluxed for $2 \mathrm{~h}$. It was then filtered, the solvent removed and was purified by $\mathrm{CC}$ (over silica gel eluting with $\mathrm{CH}_{2} \mathrm{Cl}_{2}$ ) to give compound 1 (7.5 mg). The identity was confirmed by direct co-TLC and ${ }^{1} \mathrm{H}$ NMR comparison with the sample isolated from the seed pods of $D$. trifoliata.

\section{In-vitro antiplasmodial activity assay}

The crude extract and pure compounds were assayed using a non-radioactive assay technique [8] with modifications to determine $50 \%$ growth inhibition of cultured parasites. This is an accepted method for assaying in vitro drug susceptibility using the fluorochrome called "Sybr 
Green", a non-radioactive intercalating DNA marker that accurately depicts in vitro parasite replication. This test replaces the older, ${ }^{3} \mathrm{H}$-hypoxanthine uptake assay, is fully endorsed by the WHO. Briefly, two different strains, chloroquine-sensitive Sierra Leone I (D6) and chloroquineresistant Indochina I (W2), of $P$. falciparum were grown as described in the literature [9]. The culture-adapted $P$. falciparum were added on to the plate containing dose range of drugs and incubated in a gas mixture $\left(5 \% \mathrm{CO}_{2}, 5 \% \mathrm{O}_{2}\right.$, and $\left.90 \% \mathrm{~N}_{2}\right)$ at $37{ }^{\circ} \mathrm{C}$ for $72 \mathrm{~h}$ and frozen at -80 ${ }^{\circ} \mathrm{C}$.

After thawing, lysis buffer containing SYBR green I (1 x final concentration) was added directly to the plates and gently mixed by using the Beckman Coulter Biomek 2000 automated laboratory workstation (Beckman Coulter, Inc., Fullerton, USA). The plates were incubated for 5-15 minutes at room temperature in the dark. Parasite growth inhibition was quantified by measuring the per-well relative fluorescence units (RFU) of SYBR green 1 dye using the Tecan Genios Plus (Tecan US, Inc., Durham, USA) with excitation and emission wavelengths of 485 $\mathrm{nm}$ and $535 \mathrm{~nm}$, respectively, and with the gain set at 60. Differential counts of relative fluorescence units (RFUs) were used in calculating $\mathrm{IC}_{50} \mathrm{~s}$ for each drug using Prism 4.0 software for Windows (Graphpad Software, San Diego, USA). A minimum of three separate determinations was carried out for each sample. Replicates had narrow data ranges hence presented as mean $\pm \mathrm{SD}$.

Preparation of extracts for larvicidal assay

The dry and ground plant materials (10 g each) were extracted with dichloromethane/methanol (1:1) by cold percolation. The solvents were removed under vacuum and each extract stored for larvicidal test.

Larvicidal activity assay

The larvicidal activity assay against $2^{\text {nd }}$ instar larvae of Aedes aegypti was done as described in reference [10]. LC $_{50}$ values were calculated (from the average of three observations for each concentration) using Finney's probit analysis for quantal data [11].

\section{AKNOWLEDGEMENTS}

We acknowledge support by the African Institute for Capacity Development (AICAD), Japan, the Deutsche Forschungsgemeinschaft, Germany, Grant No. Pe 264/14-5 and by the Bundesministerium fuer Zusammenarbeit, Grant No. Pe-264/14-6. Mr. S.G. Mathenge is highly appreciated for the identification of the plant material.

\section{REFERENCES}

1. Dewick, P.M. Isoflavonoids in Flavonoids: Advances in Research since 1986, Harborne, J.B. (Ed.), Chapman and Hall: London; 1994; p 117.

2. Fukami, H.; Nakajima, M. Rotenone and rotenoids in Naturally Occurring Insecticides, Jacobson, M.; Crosby, D.G. (Eds.), Marcel Dekker: New York; 1971; p 71.

3. Yenesew, A.; Mushibe, E.K.; Induli, M.; Derese, S.; Midiwo, J.O.; Kabaru, J.M.; Heydenreich, M.; Koch, A.; Peter, M.G. Phytochemistry 2005, 66, 653.

4. Yenesew, A.; Kiplagat, J.T.; Derese, S.; Midiwo, J.O.; Kabaru, J.M.; Heydenreich, M.; Peter, M.G. Phytochemistry 2006, 67, 988.

5. Yenesew, A.; Midiwo, J.O.; Miessner, M.; Heydenreich, M.; Peter, M.G. Phytochemistry 1998, 48, 1439 . 
6. Yenesew, A.; Induli, M.; Derese, S.; Midiwo, J.O.; Heydenreich, M.; Peter, M.G.; Akala, H.; Wangui, J.; Liyala P.; Waters, N.C. Phytochemistry 2004, 65, 3029.

7. Itoigawa, M.; Ito, C.; Ju-ichi, M.; Nobukuni, T.; Ichiishi, E.; Tokuda, H.; Nishino H.; Furukawa, H. Cancer Letters 2002, 176, 25.

8. Smilkstein, M.N.; Kelly, S.J.X.; Wilairat, P.; Riscoe, M. Antimicrobial Agents and Chemotherapy 2004, 48, 1803.

9. Johnson, J.D.; Dennull, R.A.; Gerena, L.; Lopez-Sanchez, M.M.; Roncal N.E.; Waters, N.C. Antimicrobial Agents and Chemotherapy 2007, 51, 1926.

10. Yenesew, A.; Derese, S.; Midiwo, J.O.; Heydenreich, M.; Peter, M.G. Pest Management Science 2003, 59, 1157.

11. McLaughlin, J.R.; Chang, C-J.; Smith, D.L.; “Bench-Top” Bioassays for Discovery of Bioactive Natural Products: an update in: Studies in Natural Products Chemistry, Vol. 99, Atta-ur-Rahman (Ed.), Elsevier Science Publishers BV: Amsterdam; 1991; p 383. 